\title{
Notes on the earthworm species, Metaphire anomala (Michaelsen, 1907) (Clitellata, Megascolecidae) in Southern Vietnam, with descriptions of two new species
}

\author{
Tung T. NGUYEN ${ }^{\circledR 1, *}$, Dang H. LAM ${ }^{\circledR 2}{ }^{2} \&$ Anh D. NGUYEN ${ }^{\circledR 3}$ \\ ${ }^{1,2}$ Department of Biology, School of Education, Can Tho University, Can Tho City, Vietnam. \\ ${ }^{3}$ Department of Soil Ecology, Institute of Ecology and Biological Resources, Vietnam. Academy of \\ Science and Technology, 18, Hoangquocviet, Caugiay, Hanoi, Vietnam. \\ ${ }^{3}$ Graduate University of Science and Technology, Vietnam Academy of Science and Technology, 18, \\ Hoangquocviet, Caugiay, Hanoi, Vietnam. \\ ${ }^{*}$ Corresponding author: thanhtung@ctu.edu.vn \\ ${ }^{2}$ Email: lamhaidangct@gmail.com \\ ${ }^{3}$ Email: ducanh410@yahoo.com \\ ${ }^{1}$ urn:1sid:zoobank.org:author:55B94873-F7A0-461A-9C33-600FE5929A28 \\ ${ }^{2}$ urn:lsid:zoobank.org:author:F41F98AF-5FE5-4063-86E4-7D7AC3F50931 \\ ${ }^{3}$ urn:lsid:zoobank.org:author:FCE53D0A-593C-4ACC-800B-E0237DC185F4
}

\begin{abstract}
Integrative taxonomy was employed to exploit the differences between the known Metaphire anomala (Michaelsen, 1907) and other specimens collected in Vietnam. The results brought to light two new species, namely Metaphire iranomala sp. nov. and Metaphire decemtheca sp. nov. The former is easily recognised by having male pores on xix and four pairs of spermathecal pores on 5/6/7/8/9 while the latter is distinguished by having five pairs of spermathecal pores on 4/5/6/7/8/9. The K2P distances of the fragment of the cytochrome c oxidase subunit I (COI) gene are $13.1 \%$ between M. iranomala sp. nov. and M. anomala (Michaelsen, 1907) and $18 \%$ between $M$. decemtheca sp. nov. and Metaphire grandiverticulata Nguyen \& Lam, 2017. The intraspecific divergences are $1.5 \%-10.6 \%$ for M. iranomala sp. nov. and $2.1 \%-11.4 \%$ for $M$. decemtheca sp. nov.
\end{abstract}

Keywords. Metaphire, taxonomy, biodiversity, COI genetic divergence, Vietnam.

Nguyen T.T., Lam D.H. \& Nguyen A.D. 2021. Notes on the earthworm species, Metaphire anomala (Michaelsen, 1907) (Clitellata, Megascolecidae) in Southern Vietnam, with descriptions of two new species. European Journal of Taxonomy 746: 94-111. https://doi.org/10.5852/ejt.2021.746.1321

\section{Introduction}

Michaelsen (1907) described a new species, namely Pheretima anomala, from only eight specimens collected from the Botanical Gardens of Sibpur, Calcutta (India). The species is very specific without spermathecae and male pores on segment xx. Later, Gates (1925) commented on the species based on specimens collected from Rangoon (Myanmar). His specimens were slightly different from the 
original description (length 116-162 mm vs $80-90 \mathrm{~mm}$, papillae on xviii-xxii vs on xvii-xxiii). Gates (1925) also described a new species, P. insolita. The species contained six types (A, B, C, D, $\mathrm{E}, \mathrm{F})$ distinguishable in length, diameter, number of segments, location and numbers of papillae in the male region. Pheretima insolita was very similar to $P$. anomala in terms of traces of male pores on $\mathrm{xx}$, but differs in having spermathecal pores on 5/6/7/8 and variations of papillae in the male region. Stephenson (1929) discussed all types of $P$. insolita and $P$. anomala. He commented that the original specimens ( $P$. anomala) possibly acted as functional males while the functional females would be $P$. insolita. Stephenson (1929), therefore, suggested to unite all the forms of $P$. anomala and $P$. insolita as one species, $P$. anomala. Michaelsen (1907)'s specimens would constitute the forma typical.

Metaphire anomala (Michaelsen, 1907) is widely distributed in India, Myanmar, Thailand, Laos, Yunnan (China) and Northern Vietnam (Michaelsen 1907; Gates 1925, 1972; Stephenson 1929; Nguyen et al. 2016; Yuan et al. 2019). However, M. anomala is highly variable due to parthenogenetic degeneration, and often specimens without spermathecae or without male pores are dominant (Gates 1925, 1972; Stephenson 1929). If present, the spermathecal pores are in 5/6/7/8 and/or male pores are in $\mathrm{xx}$.

The species Metaphire anomala has previously been reported in Southern Vietnam as 'so-called' Pheretima anomala Michaelsen, 1907. It is widely distributed in Southern Vietnam: Ba Ria-Vung Tau (Con Lon Isl.), Dong Nai (Cat Tien), Kien Giang (Lai Son Isl., Phu Quoc Isl.), An Giang (Nhon Mts, Phu Cuong Mts, Ba Doi Mts, Cam Mts, To Mts), Dong Nai (Vinh Cuu, Xuan Loc, Dinh Quan, Trang Bom, Cam My, Long Thanh, Cat Tien NP), Tay Ninh (Ba Den Mts) (Thai et al. 2004; Nguyen 2014; Nguyen et al. 2016, 2017a, 2017b, 2019, 2020).

During our re-examination of previously and newly collected specimens housed at Can Tho University, we found that the specimens collected from Southern Vietnam were very different from their original description (Michaelsen 1907), Gates $(1925,1972)$ and recent re-description (Bantaogwon et al. 2011). An integrative approach combining morphological and molecular data was used to confirm the taxonomic status of the Vietnamese specimens. Two new species were discovered and named in this study.

\section{Material and methods}

Earthworms were manually searched and previously collected in Vietnam. After collection, specimens were cleaned with tap water, killed in formalin $2 \%$, temporarilly fixed in formalin $4 \%$ for 12 hours, then transferred to new formalin $4 \%$ for long-term preservation for morphological study. Specimens for molecular study were preserved in ethanol 90\%. Specimens including holotypes and paratypes were deposited in Laboratory of Zoology, Department of Biology, CTU. Some were shared with the Department of Soil Ecology, Institute of Ecology and Biological Resources (IEBR), Hanoi, Vietnam.

\section{Morphological examination}

Material was examined under a Motic Digital microscope (model: DM143-FBGG-C) and dissected from the dorsal side for internal observation. Transverse body sections were processed using the classical method of haematoxylin and eosin. Selected segments were cleaned and dehydrated using graded ethanol concentrations. Segments were treated with paraffin, then cut using a microtome Sakura Accu SRM 200CW. The cut sections were stained using haematoxylin and eosin Y (Feldman \& Wolfe 2014), then transferred onto glass slides. 
Colour images were taken using a camera attached directly to the microscope. Line drawings and colour images were improved and grouped into plates using Photoshop CS6.

\section{DNA extraction, PCR reaction and phylogenetic analysis}

Total genomic DNA was extracted from the body walls of segments 30-35 using the DNAeasy Blood \& Tissue Kit (QiagenTM). A 680bp fragment of the cytochrome c oxidase subunit I (COI) mitochondrial gene was amplified using the polymerase chain reaction (PCR) method with the universal primer set (HCO-2190/COI-E and LCO-1498/LCO-1498m) (Folmer et al. 1994). The PCR conditions for amplification were as follows: an initial denaturation at $95^{\circ} \mathrm{C}$ for 2 min followed by 36 cycles of $95^{\circ} \mathrm{C}$ for $20 \mathrm{~s}, 42^{\circ} \mathrm{C}$ for $45 \mathrm{~s}$, and $72^{\circ} \mathrm{C}$ for $1 \mathrm{~min}$, and a final extension at $72^{\circ} \mathrm{C}$ for $5 \mathrm{~min}$. PCR products were checked for potentially successful amplification using electrophoresis in 1\% Agarose-TBE 1X. Successfully amplified PCR products were purified and sequenced at FishBase, Inc. (Malaysia) on an Applied Biosystems automatic sequencer (ABI3130 XL). Each successful sequence was manually checked using BioEdit ver. 7.1 (Hall 1999) and confirmed using BLASTN 2.6.0+ searches (Zhang et al. 2000). All confirmed sequences were aligned with MUSCLE (Edgar 2004). All nucleotide sequences have been deposited in GenBank (NCBI).

The dataset contained COI sequences from two new species and five other Metaphire sequences (M. anomala, M. bahli [Gates, 1945], M. grandiverticulata Nguyen \& Lam, 2017, M. megascolidioides [Goto \& Hatai, 1899] and M. peguana [Rosa, 1890]) (Table 1). Polypheretima elongate (Perrier, 1872) was selected as an outgroup, as Polypheretima is a sister genus of Metaphire (see Sims \& Easton 1972). The genetic distance was calculated using the Kimura 2 parameter (K2P) model performed in MEGA ver. 7.0 with 1000 bootstrap replicates (Kumar et al. 2016).

ModelFinder performed in IQ-TREE ver. 1.6.12 was applied to find the best-fit maximum likelihood site substitution model (Kalyaanamoorthy et al. 2017). The substitution model, TIM2+F+I+G4, was selected using a likelihood ratio test with $-\operatorname{lnL}=3509.852$ and BIC score $=7513.414$. A maximum likelihood bootstrap analysis was conducted using IQ-TREE ver. 2.1.1 with 1000 pseudoreplicates (Minh et al. 2020). A Bayesian inference (BI) tree was inferred using MrBayes ver. 3.2 (Ronquist et al. 2012) with 10 million generations, heating parameter of 0.06 , burnin of $10 \%$ and sampling every 1000 generations.

Abbreviations
ag $=$ accessory gland
amp $=$ ampulla
$\mathrm{B} \quad=$ Bayesian Inference
$\mathrm{CTU}=$ Can Tho University
$\mathrm{dv}=$ diverticulum
$\mathrm{IEBR}=$ Institute of Ecology and Biological Resources
$\mathrm{gm}=$ genital marking
$\mathrm{ML} \quad=$ Maximum Likelihood
$\mathrm{mp} \quad=$ male pore
ov $=$ ovary
$\mathrm{os}=$ ovary sac
$\mathrm{sp}=$ spermathecal pore
$\mathrm{sv} \quad=$ seminal vesicle
$\mathrm{ts}=$ testis sac


NGUYEN T.T. et al., Two new Metaphire species from Southern Vietnam

Table 1. Specimen vouchers and accession numbers deposited in GenBank

\begin{tabular}{|c|c|c|c|c|}
\hline No. & Species & Locality & Specimen voucher & $\begin{array}{l}\text { Accession } \\
\text { number }\end{array}$ \\
\hline 1 & Metaphire bahli (Gates, 1945) & Ba Ria-Vung Tau Prov. & CTU-EW.004.12 & MW076178 \\
\hline 2 & Metaphire bahli (Gates, 1945) & Binh Phuoc Prov. & CTU-EW.004.23 & MW076179 \\
\hline 3 & Metaphire bahli (Gates, 1945) & Binh Duong Prov. & CTU-EW.004.26 & MW076180 \\
\hline 4 & Metaphire bahli (Gates, 1945) & Ho Chi Minh city & CTU-EW.004.41 & MW076181 \\
\hline 5 & Metaphire bahli (Gates, 1945) & Tay Ninh Prov. & CTU-EW.004.42 & MW076182 \\
\hline 6 & Metaphire bahli (Gates, 1945) & Dong Nai Prov. & CTU-EW.004.43 & MW076183 \\
\hline 7 & Metaphire bahli (Gates, 1945) & Ba Ria-Vung Tau Prov. & CTU-EW.004.44 & MW076184 \\
\hline 8 & Metaphire peguana (Rosa, 1890) & Ba Ria-Vung Tau Prov. & CTU-EW.009.06 & MW076185 \\
\hline 9 & Metaphire peguana (Rosa, 1890) & Binh Duong Prov. & CTU-EW.009.07 & MW076186 \\
\hline 10 & Metaphire peguana (Rosa, 1890) & Binh Phuoc Prov. & CTU-EW.009.10 & MW076187 \\
\hline 11 & Metaphire peguana (Rosa, 1890) & Ho Chi Minh city & CTU-EW.009.13 & MW076188 \\
\hline 12 & Metaphire peguana (Rosa, 1890) & Dong Nai Prov. & CTU-EW.009.15 & MW076189 \\
\hline 13 & Metaphire peguana (Rosa, 1890) & Ba Ria-Vung Tau Prov. & CTU-EW.009.16 & MW076190 \\
\hline 14 & Metaphire iranomala sp. nov. & Tay Ninh Prov. & CTU-EW.020.16 & MW076191 \\
\hline 15 & Metaphire iranomala sp. nov. & $\begin{array}{l}\text { Chau Duc Distr., Ba Ria } \\
\text {-Vung Tau Prov. }\end{array}$ & CTU-EW.020.19 & MW076193 \\
\hline 16 & Metaphire iranomala sp. nov. & $\begin{array}{l}\text { Con Son isl., Ba Ria } \\
\text {-Vung Tau Prov. }\end{array}$ & CTU-EW.020.20 & MW076194 \\
\hline 17 & Metaphire iranomala sp. nov. & $\begin{array}{l}\text { Con Son isl., Ba Ria } \\
\text {-Vung Tau Prov. }\end{array}$ & CTU-EW.020.20b & MW076195 \\
\hline 18 & Metaphire iranomala sp. nov. & $\begin{array}{l}\text { Vinh Cuu Distr., } \\
\text { Dong Nai Prov. }\end{array}$ & CTU-EW.020.18 & MW076192 \\
\hline 19 & Metaphire iranomala sp. nov. & Kien Giang Prov. & CTU-EW.020.23 & MW076196 \\
\hline 20 & $\begin{array}{l}\text { Metaphire grandiverticulata } \\
\text { Nguyen \& Lam, } 2017\end{array}$ & Ho Chi Minh city & CTU-EW.089.4a & MW076200 \\
\hline 21 & $\begin{array}{l}\text { Metaphire grandiverticulata } \\
\text { Nguyen \& Lam, } 2017\end{array}$ & Ho Chi Minh city & CTU-EW.089.4a1 & MW076199 \\
\hline 22 & Metaphire decemtheca sp. nov. & $\begin{array}{l}\text { Con Son isl., Ba Ria } \\
\text {-Vung Tau Prov. }\end{array}$ & CTU-EW.183.p02 & MW076203 \\
\hline 23 & Metaphire decemtheca sp. nov. & $\begin{array}{l}\text { Con Son isl., Ba Ria } \\
\text {-Vung Tau Prov. }\end{array}$ & CTU-EW.183.03 & MW076202 \\
\hline 24 & Metaphire decemtheca sp. nov. & $\begin{array}{l}\text { Con Son isl., Ba Ria } \\
\text {-Vung Tau Prov. }\end{array}$ & CTU-EW.1183.06 & MW076201 \\
\hline 25 & $\begin{array}{l}\text { Polypheretima elongata } \\
\text { (Perrier, 1872) }\end{array}$ & Ho Chi Minh city & CTU-EW.026.02 & MW076197 \\
\hline 26 & $\begin{array}{l}\text { Polypheretima elongata } \\
\text { (Perrier, } 1872 \text { ) }\end{array}$ & Ho Chi Minh city & CTU-EW.026.02b & MW076198 \\
\hline 27 & Metaphire bahli (Gates, 1945) & Prasankok et al. (2013) & & KC404844 \\
\hline 28 & Metaphire bahli (Gates, 1945) & Blakemore (2016a) & & KT626598 \\
\hline 29 & Metaphire peguana (Rosa, 1890) & Prasankok et al. (2013) & & KC404831 \\
\hline 30 & Metaphire peguana (Rosa, 1890) & Jeratthitikul et al. (2017) & & KU565288 \\
\hline 31 & $\begin{array}{l}\text { Metaphire anomala } \\
\text { (Michaelsen, 1907) }\end{array}$ & Bantaowong et al. (2011) & & KC565251 \\
\hline 32 & $\begin{array}{l}\text { Metaphire anomala } \\
\text { (Michaelsen, 1907) }\end{array}$ & Bantaowong et al. (2011) & & KC565252 \\
\hline 33 & $\begin{array}{l}\text { Metaphire anomala } \\
\text { (Michaelsen, 1907) }\end{array}$ & Bantaowong et al. (2011) & & KC565253 \\
\hline 34 & $\begin{array}{l}\text { Metaphire anomala } \\
\text { (Michaelsen, 1907) }\end{array}$ & Bantaowong et al. (2011) & & KC565254 \\
\hline 35 & $\begin{array}{l}\text { Metaphire megascolidioides } \\
\text { (Goto \& Hatai, 1899) }\end{array}$ & Blakemore (2016b) & $\begin{array}{l}\text { Sequence is } \\
\text { presented in the paper }\end{array}$ & \\
\hline 36 & $\begin{array}{l}\text { Metaphire megascolidioides } \\
\text { (Goto \& Hatai, 1899) }\end{array}$ & Minamiya et al. (2009) & & AB482107 \\
\hline
\end{tabular}




\section{Results}

\section{Descriptions of new species}

Class Clitellata Michaelsen, 1919

Subclass Oligochaeta Grube, 1850

Order Opisthopora Michaelsen, 1929

Suborder Crassiclitellata Jamieson, 1988

Family Megascolecidae Rosa, 1891

Genus Metaphire Sims \& Easton, 1972

Metaphire iranomala sp. nov. urn:Isid:zoobank.org:act:2ECB8639-C770-4828-92D9-055E0778E422

Figs $1-3$, Tables $2-3$

Pheretima anomala (non Pheretima anomala Michaelsen, 1907) - Thai et al. 2004: 758. - Nguyen 2014: 108. - Nguyen et al. 2017a: 893, fig. 7; 2017b: 98, fig. 3; Nguyen et al. 2019: 120, fig. 3. Metaphire anomala - Nguyen et al. 2016: 50.

\section{Diagnosis}

Medium-sized worm, length $157-228 \mathrm{~mm}$, diameter $6.5-8.0 \mathrm{~mm}$, segments $85-145$. Prostomium epilobous. Clitellum annular, within xiv-xvi. First dorsal pore in $12 / 13$. Four pairs of spermathecal pores on ventrolateral intersegments 5/6/7/8/9. Male pores on the setal ring of segment xix; copulatory pouches present. Genital markings absent. Holandric. Testis sacs connected. Intestinal caeca simple. Septa 8/9/10 absent.

\section{Etymology}

The epithet 'iranomala' is formed by the prefix 'ir' and 'anomala' to emphasise the wrong name 'anomala' recorded in Vietnam.

\section{Material examined}

\section{Holotype}

VIETNAM • mature spec.; Ba Ria-Vung Tau Province, Con Dao National Park; 842'12"N; 106 35'41" E; 120 m a.s.l.; 19 Oct. 2019; Nguyen Thanh Tung and Nguyen Thi Bao Ngoc leg.; natural forest; CTU-EW.020.h01.

\section{Paratypes}

VIETNAM • 9 matures; same collection data as for holotype; CTU-EW.020.p02.

\section{Other material}

VIETNAM - Ba Ria-Vung Tau Province - 16 matures; same collection data as for holotype; CTU-EW.020.03 • 10 matures; Con Son Island; 841'59" N, 106³6'54" E; 10 m a.s.1.; 18 Oct. 2019; Nguyen Thanh Tung and Nguyen Thi Bao Ngoc leg.; residential gardens; CTU-EW.020.04 33 matures; Con Son Island; 8³9'53" N, 106 34'00" E; 20 m a.s.l.; 19 Oct. 2019; Nguyen Thanh Tung and Nguyen Thi Bao Ngoc leg.; natural forest; CTU-EW.020.05. - Kien Giang Province • 1 mature; Da Dung mountain; $10^{\circ} 25^{\prime} 07^{\prime \prime} \mathrm{N}, 104^{\circ} 28^{\prime} 46^{\prime \prime}$ E; Nov. 2010; Nguyen Thanh Tung leg.; natural forest; CTUEW.DNA.020.23 • 49 matures; Lai Son Island; 0948'01" N, 104³9'18" E; Nov. 2013; Trinh Thi Kim Binh leg.; natural forest; CTU-EW.020.11. - An Giang Province • 57 matures; Cam mountain; $10^{\circ} 30^{\prime} 36^{\prime \prime}$ N, $105^{\circ} 00^{\prime} 09^{\prime \prime}$ E; Nov. 2010; Nguyen Thanh Tung leg.; natural forest; CTU-EW.020.12

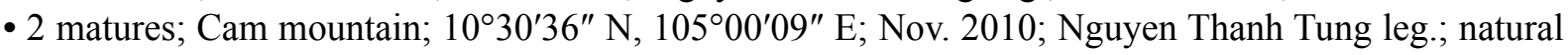


forest; IEBR-EW.020.22. - Dong Nai Province - 2 matures; Vinh Cuu Nature Reserve; $11^{\circ} 06^{\prime} 46^{\prime \prime} \mathrm{N}$, $107^{\circ} 03^{\prime} 12^{\prime \prime}$ E; Oct. 2019; Nguyen Quoc Nam leg.; natural forest; IEBR-EW.020.18a • 3 matures; Vinh Cuu Nature Reserve; $11^{\circ} 06^{\prime} 46^{\prime \prime}$ N, 107 03'12" E; Oct. 2019; Nguyen Quoc Nam leg.; natural forest;

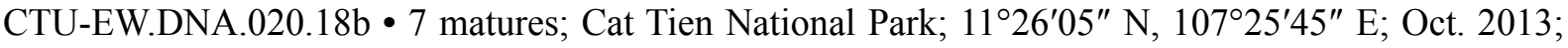
Le Van Nhan leg.; natural forest; CTU-EW.020.07. - Tay Ninh Province • 1 mature; Duong minh Chau District; $11^{\circ} 22^{\prime} 59^{\prime \prime}$ N, $106^{\circ} 12^{\prime} 00^{\prime \prime}$ E; Sep. 2019; Nguyen Quoc Nam leg.; home garden; IEBR-EW.020.16 • 6 matures; Ba Den mountain; 11²3'26" N, 10609'19" E; Sep. 2019; Nguyen Quoc Nam leg.; mango gardens; CTU-EW.020.17.

\section{Description}

Body cylindrical, large-medium size, length $157-228 \mathrm{~mm}$, diameter $6.5-8.0 \mathrm{~mm}$, segments $85-145$, weight 3.0-8.4 gr. Dorsum slightly dark grey, ventrum paler. Prostomium epilobous. First dorsal pore in $12 / 13$. Perichaetine, setae at pre-clitellar segments stouter and sparser than that at post-clitellar segments; setal numbers: $55-62$ in viii, $65-71$ in $\mathrm{xxx}, 10-16$ between male pores on xix. Setal distance: $a a>a b, z z>$ zy. Clitellum annular, within xiv-xvi, darkish brown, without dorsal pores and setae. Female pore single, mid-ventral in xiv.

Four pairs of spermathecal pores on ventrolateral intersegments 5/6/7/8/9. Ventral distance between spermathecal pores ca $0.27-0.3$ body circumference. Male pores on copulatory pouches in xix; ventral distance between male pores ca $0.2-0.3$ body circumference. Genital markings absent in both spermathecal and male pores region.

Septa 5/6/7/8 thickened, 8/9/10 absent, 10/11/12 thin. Oesophageal gizzard between 7/8 and 10/11. Intestine origin at xv; caeca simple, short within xxvii-xxiv. Last hearts in xiii. Pharyngeal micronephridia developed in 5/6/7. Lymph glands absent. Typhlosole simple, lamelliform.

Spermathecae paired in vi-ix. Spermathecal ampulla large, mango-shaped; duct about a quarter of ampulla length. Diverticula attached to the base of ampulla ducts; distal part strongly coiled, swollen into coiled sinusoidal seminal chambers. Spermathecal ducts without nephridia. Accessory glands absent in the spermathecal region.

Holandric. Testis sacs in x and xi, connected ventrally. Seminal vesicles well developed in xi and xii. Ovaries on septum 12/13 posteriorly. Prostate glands, deeply lobuled, paired in xvii-xxi; prostatic ducts $\mathrm{C}$-shaped. Accessory glands massed, covered the copulatory pouches.

\section{DNA barcode}

COI barcode data (partial) is for the paratypes uploaded to GenBank under the accession numbers MW076191, MW076192, MW076193, MW076194, MW076195, and MW076196. The new species shares the identity of $88.13 \%$ and $88.33 \%$ with Metaphire anomala (KU262251, KU565252, KU565253, KU565254).

\section{Habitat}

The species was found in leaf-litters or in the top-soil layer, especially in moist places (near streams) or in rocky holes with organic matter. Metaphire iranomala sp. nov. has a soft body, violet light skin when alive. Its moving behavior is similar to a caterpillar locomotion. The species was commonly located in hilly/mountainous areas, but occasionally found in deltas.

\section{Variations}

Metaphire iranomala sp. nov. has two slightly different morphological types. The first type is more likely to be distributed in islands or in coastal provinces in Vietnam; the other type is found in mainland provinces. 

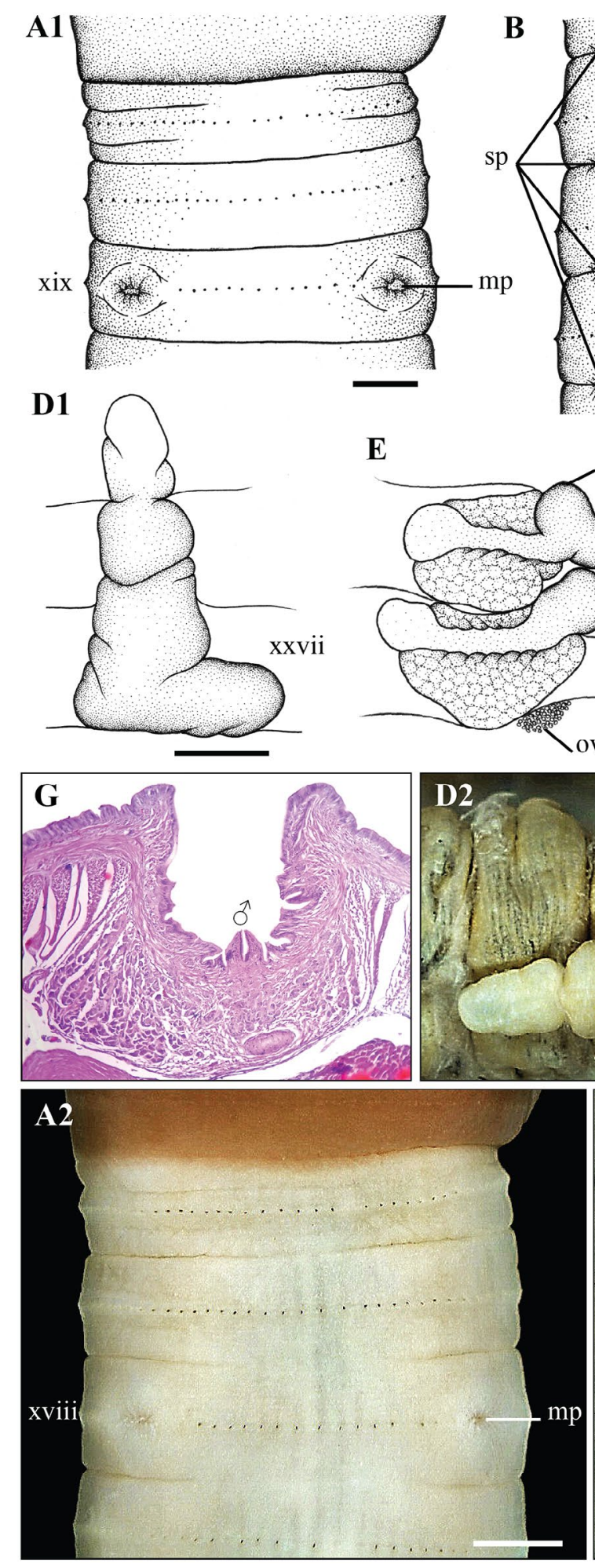

B
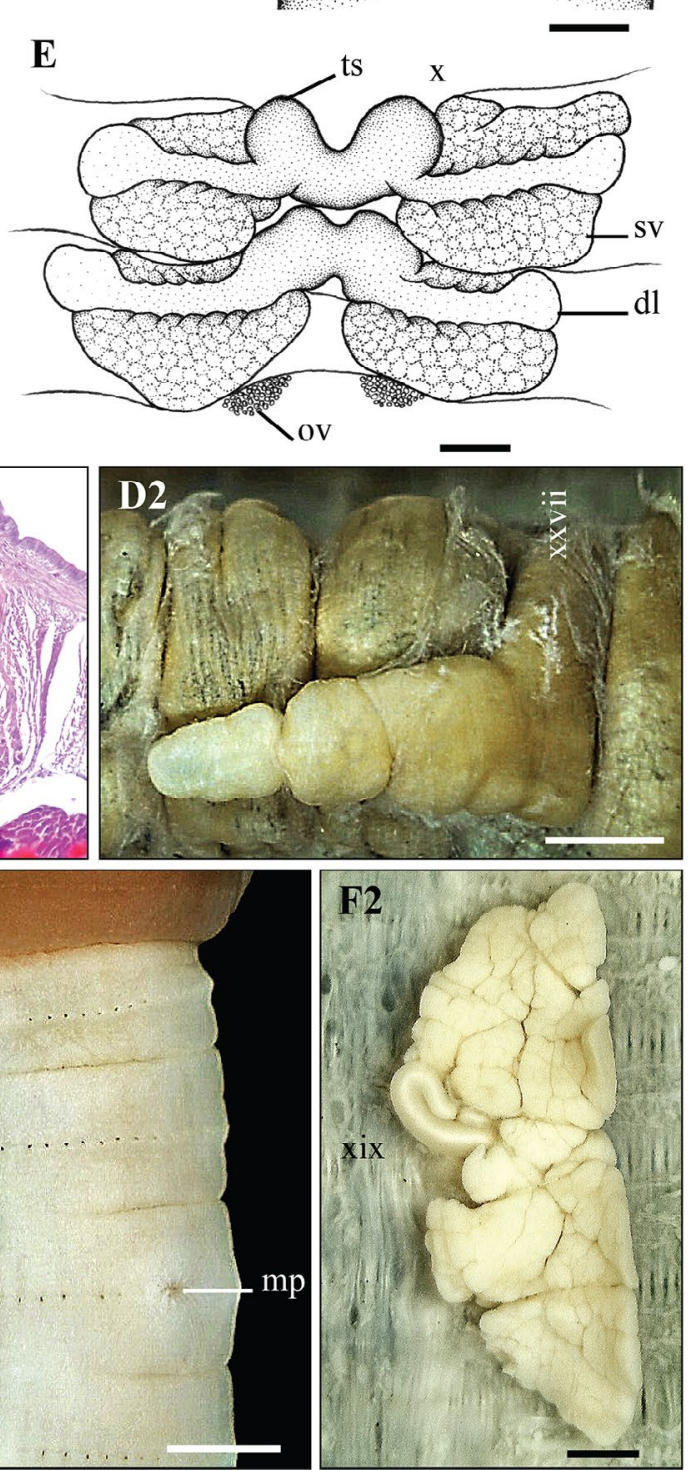

C1
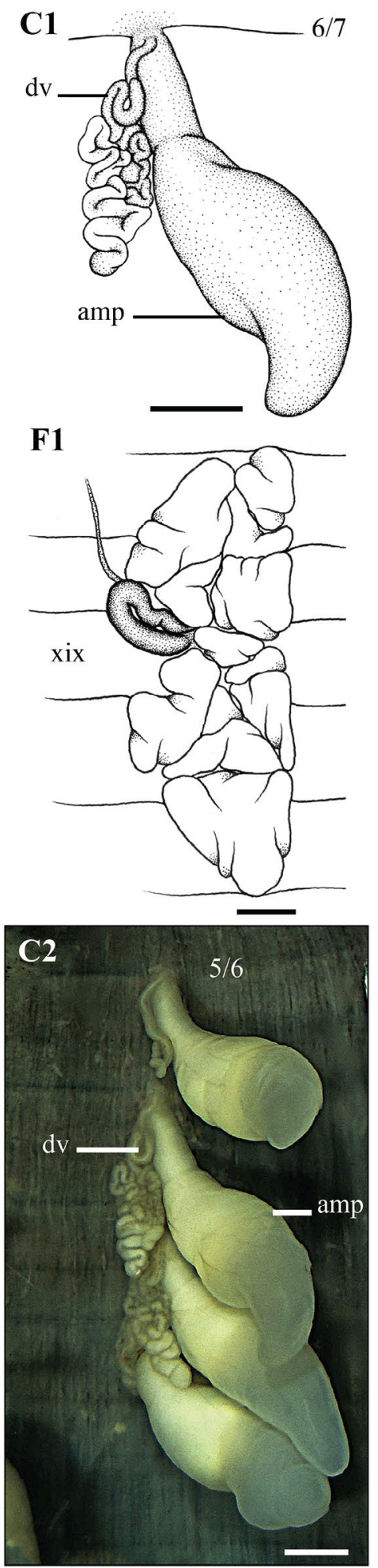

Fig. 1. Metaphire iranomala sp. nov., holotype (CTU-EW.020.h01). A1, A2. Ventral view of male pores region. B. Lateral view of spermathecal pores region. C1, C2. Right spermathecae. D1, D2. Intestinal caecum. E. Testis sacs and seminal vesicles. F1, F2. Right prostatic gland. G. Copulatory pouch transverse body section. Scale bars $=1 \mathrm{~mm}$. 

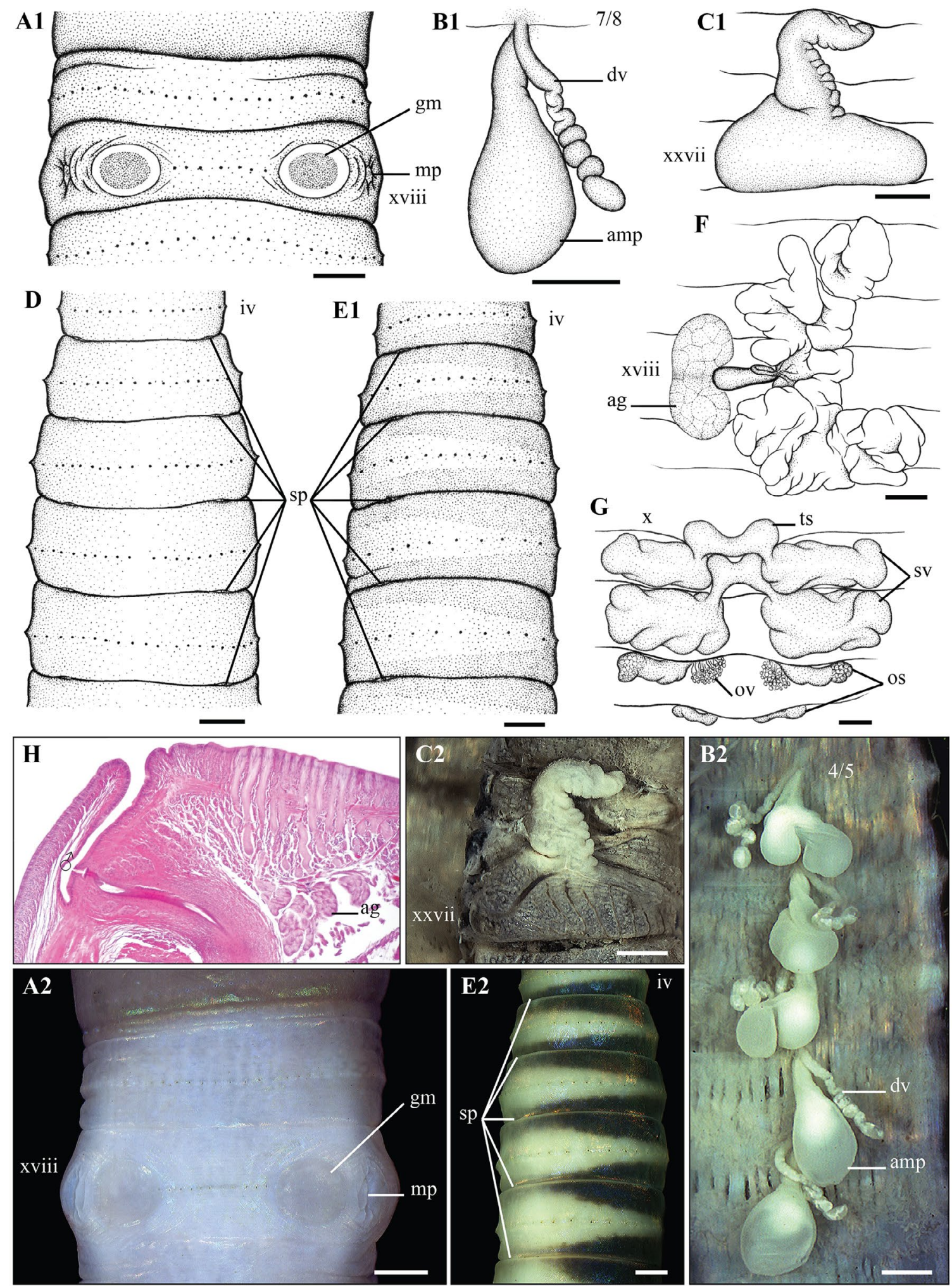

Fig. 2. Metaphire decemtheca sp. nov., holotype (CTU-EW.183.h01). A1, A2. Ventral view of male pore region. B1, B2. Right spermathecae. C1, C2. Intestinal caecum. D. Ventral view of spermathecal pore region. E1, E2. Lateral view of spermathecal pores region. F1, F2. Left prostatic gland. G. Testis sacs and seminal vesicles. H. Male pore region transverse body section. Scale bars $=1 \mathrm{~mm}$. 
Table 2. Comparison between M. iranomala sp. nov. and M. anomala (Michaelsen, 1907) from Thailand, Myanmar and India (its original description).

\begin{tabular}{|c|c|c|c|c|}
\hline Characteristics & Vietnam ${ }^{1}$ & Thailand $^{2}$ & Myanmar ${ }^{3}$ & $\begin{array}{c}\text { Original } \\
\text { description } \\
\text { (India) }^{4}\end{array}$ \\
\hline Length & $157-228$ & 134-154 & $116-200$ & $80-90$ \\
\hline Diameter & $6.5-8.0$ & $4.6-6.7$ & $3.0-7.0$ & $5.0-5.5$ \\
\hline Segment & $85-145$ & $116-126$ & 119-130 & 130 \\
\hline Spermathecal pores & $\begin{array}{l}\text { four pairs in } \\
5 / 6 / 7 / 8 / 9\end{array}$ & 3 pairs in $5 / 6 / 7 / 8$ & absent or $5 / 6 / 7 / 8$ & absent \\
\hline Pre-clitellar setae & 46-53 (viii) & $84-96$ & 90-96 (viii) & $70(\mathrm{v})$ \\
\hline Post-clitellar setae & $62-71(\mathrm{xxx})$ & $58-67$ & $61-70(x x)$ & $74(\mathrm{xxv})$ \\
\hline Male pores & xix & $\mathrm{xx}$ & $\mathrm{xx}$ & $\mathrm{xx}$ \\
\hline $\begin{array}{l}\text { Ventral distance } \\
\text { between male pores }\end{array}$ & $0.2-0.3$ & 0.33 & - & 0.17 \\
\hline Genital markings & absent & $\begin{array}{l}\text { 3-6 pairs in xvii-xix, } \\
\text { xxi-xxiii or absent }\end{array}$ & $\begin{array}{l}\text { present in xvii-xix } \\
\text { and xxi-xxiv }\end{array}$ & $\begin{array}{l}4 \text { pairs in xviii- } \\
\text { xix, xxi-xxii }\end{array}$ \\
\hline Septum $8 / 9$ & absent & absent & present & present \\
\hline Testis sacs & connected & separated & separated & separated \\
\hline
\end{tabular}

${ }^{1}$ Freshly collected specimens; ${ }^{2}$ Bantaowong et al. $(2011) ;{ }^{3}$ Gates $(1925,1972)$ and Stephenson $(1929) ;{ }^{4}$ Michaelsen (1907).

Table 3. Comparison between M. iranomala sp. nov., M. megascolidioides (Cognetti, 1908) and M. isselii (Goto \& Hatai, 1899) sharing location of male pores not in segment xix.

\begin{tabular}{|c|c|c|c|}
\hline Characteristics & M. iranomala & M. megascolidioides ${ }^{1}$ & M. isselii ${ }^{2}$ \\
\hline Length & $157-228$ & 240 & $155-180$ \\
\hline Diameter & $6.5-8.0$ & 15 & 10 \\
\hline Segment & $85-145$ & 118 & $94-115$ \\
\hline Spermathecal pore & lateroventral, 5/6/7/8/9 & lateroventral, 4/5/6/7/8/9 & ventral, $6 / 7 / 8 / 9$ \\
\hline $\begin{array}{l}\text { Setal number } \\
\text { between two male pores }\end{array}$ & $10-16$ & 9 & 0 \\
\hline $\begin{array}{l}\text { Ventral distance } \\
\text { between two male pores }\end{array}$ & $0.2-0.3$ & $?$ & $<0.25$ \\
\hline $\begin{array}{l}\text { Genital markings } \\
\text { in male region }\end{array}$ & absent & $\begin{array}{l}3 \text { pairs in } x v i i, x v i i i \\
\text { and } x x\end{array}$ & $\begin{array}{c}2 \text { pairs in } 18 / 19 \\
\text { and } 19 / 20\end{array}$ \\
\hline Septum 8/9 & absent & absent & thin \\
\hline Intestinal caeca & simple & manicate & simple \\
\hline Intestinal origin & $\mathrm{xV}$ & $\mathrm{xv}$ & xvi \\
\hline
\end{tabular}

${ }^{1}$ Goto \& Hatai (1899) and Blakemore (2016b); ${ }^{2}$ Cognetti (1908).

There are not many differences between the two types except the ventral distance between the male pores (0.2-0.22 vs 0.25-0.3). However, the COI genetic distance also distinguishes two types (see below).

\section{Remarks}

The new species has been previously identified as Metaphire anomala. It is widely distributed in Southern Vietnam (Thai et al. 2004; Nguyen 2014; Nguyen et al. 2017a, 2017b, 2019, 2020). However, 
this species is very different from both the original description (Michaelsen 1907), and re-description of M. anomala from Myanmar (Gates 1925, 1972), Thailand (Bantaowong et al. 2011) in the position of male pores, number and position of spermathecal pores, genital markings in male and spermathecal regions and body size. These differences are summarised in Table 2.

A few Metaphire species have been known to exhibit male pores not in segment xviii. Only M. anomala has male pores on xx, whereas two other species, M. isselii Cognetti, 1908 and M. megascolidioides Goto \& Hatai, 1899, have male pores on xix. The new species is similar to these two species by having male pores on xix, a first dorsal pore in $12 / 13$ and the absence of genital markings in the spermathecal region. However, the new earthworm species is clearly distinguished by body size, the number and position of spermathecal pores, the morphology of its male region, the status of septum $8 / 9$, and they type of intestinal caeca. The differences are summarised in Table 3.

Metaphire decemtheca sp. nov.

urn:1sid:zoobank.org:act:F717F325-F04E-409A-93B1-0A3997E11E9E

Figs 2-3

\section{Diagnosis}

Medium-sized worm. Prostomium epilobous. First dorsal pore in 12/13. Clitellum annular, within xivxvi. Five pairs of spermathecal pores on ventrolateral intersegments 4/5/6/7/8/9. Male pores on the setal ring of xviii; copulatory pouches present. A pair of genital markings in xviii. Holandric. Testis sacs connected. Intestinal caeca simple. Septum $8 / 9$ absent or very thin, 9/10 absent.

\section{Etymology}

The epithet 'decemtheca' emphasises the number of spermathecae of the new species.

\section{Material examined}

Holotype

VIETNAM • mature; Ba Ria-Vung Tau Province, Con Son Island; 8 42'17" N, 106³5'28" E; 50 m a.s.1.; 19 Oct. 2019; Nguyen Thanh Tung and Nguyen Thi Bao Ngoc leg.; natural forest; CTU-EW.183.h01.

\section{Paratypes}

VIETNAM • 9 matures; same collection data as for holotype; CTU-EW.183.p02.

\section{Other material}

VIETNAM - Ba Ria-Vung Tau Province - 38 matures; same collection data as for holotype; CTU-EW.183.03 • 23 matures; Con Son Island; 843'50" N, 106³7'31" E; 10 m a.s.l.; 18 Oct. 2019; Nguyen Thanh Tung and Nguyen Thi Bao Ngoc leg.; natural forest; CTU-EW.183.04 • 55 matures; Con Son Island; $8^{\circ} 43^{\prime} 59^{\prime \prime}$ N, 106 37'21" E; 10 m a.s.1.; 18 Oct. 2019; Nguyen Thanh Tung and Nguyen Thi Bao Ngoc leg.; residential gardens; CTU-EW.183.05.

\section{Description}

Body cylindrical, medium-sized worms. Length $64-185 \mathrm{~mm}$, diameter ca 3.0-6.0 mm, segments 79124, weight 1.1-3.9 gr. Dorsum slightly dark grey with reddish browns stripes or absent, ventrum paler. Prostomium epilobous. First dorsal pore in 12/13. Perichaetine; setae at pre-clitellar segments stouter and sparser than that at post-clitella segments; setal numbers: $38-51$ in viii, $46-57$ in xxx, 8-13 between two male pores on xviii. Setal distance: aa $>a b, z z=z y$. Clitellum annular (3/4xiv-3/4xvi), slightly brown, without dorsal pores and setae. Female pore single, mid-ventral in xiv. 
Five pairs of spermathecal pores on ventrolateral intersegments 4/5/6/7/8/9. Ventral distance between spermathecal pores ca $0.38-0.45$ body circumference. Genital markings absent in spermathecal region. Male pores on line with setal ring in xviii; copulatory pouches present; ventral distance between male pores is 0.38 body circumference. One pair of flat ellipsoidal genital markings in xviii located next to male pores ventrally.

Septa 5/6/7/8 thick, 8/9 absent or membrane (if present), 9/10 absent, 10/11/12/13 thin. Oesophageal gizzard between $7 / 8$ and 10/11. Intestine origin at xv; caeca simple, somewhat rudimentary lobulated dorsally, within xxvii-xxv. Last hearts in xiii. Pharyngeal micronephridia developed in 5/6/7. Lymph glands sac-like, present from 27/28. Typhlosole simple, lamelliform.

Spermathecal paired in v-ix. Spermathecal ampulla oval-shaped, ducts stout, short, about one-third of ampulla length. Diverticula shorter than ampulla, strongly and constrainedly waved, attached to the base of ampulla

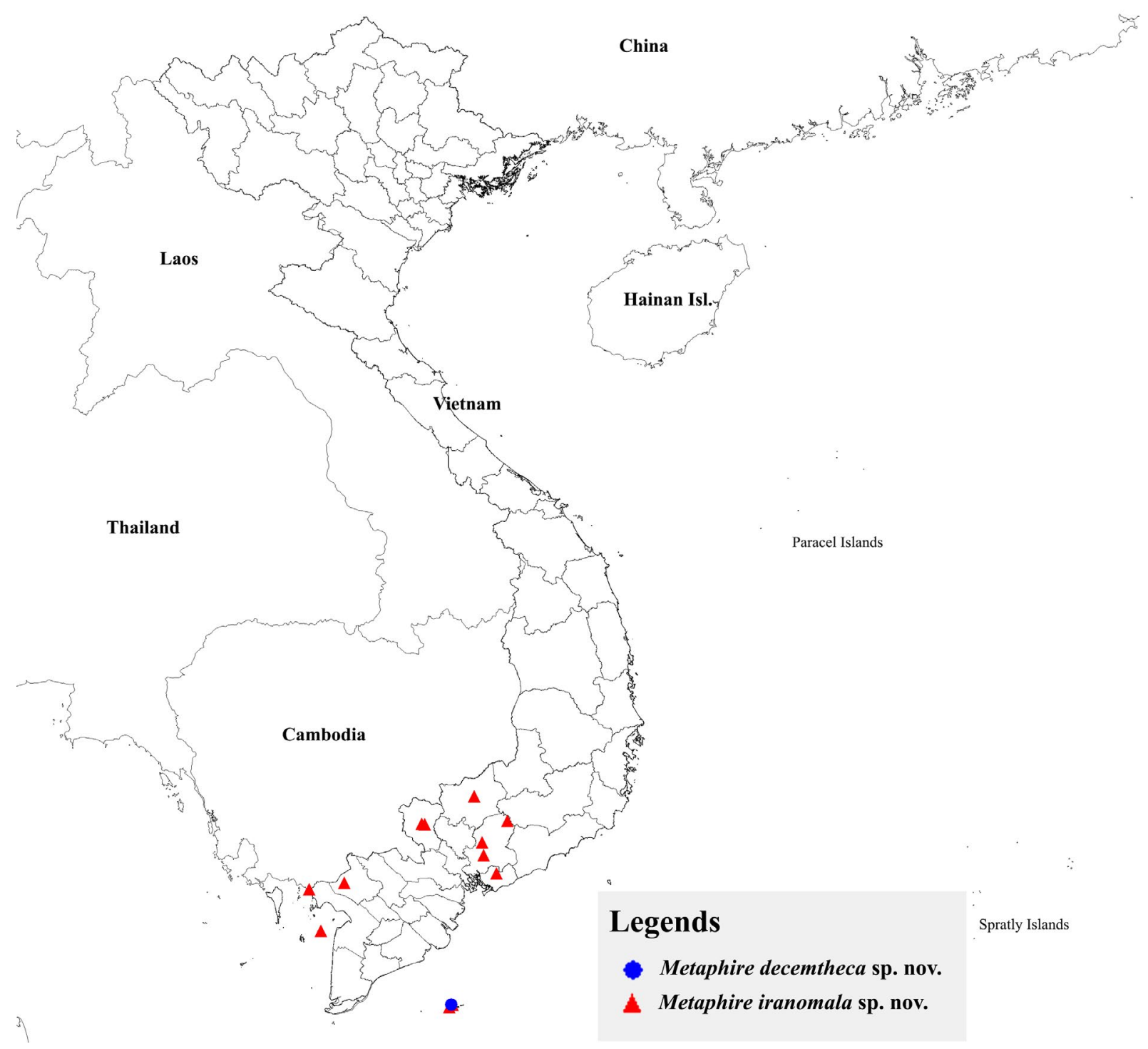

Fig. 3. The distribution of the two new species in Southern Vietnam. 
ducts; seminal chamber small oval-shaped. Spermathecal ducts without nephridia. Accessory glands absent in the spermathecal region.

Holandric. Testis sacs in $\mathrm{x}$ and $\mathrm{xi}$, connected ventrally. Seminal vesicles developed in xi and xii. Ovaries on septum 12/13 posteriorly. Ovisacs developed on 12/13, poorly developed on 13/14. Prostate glands deeply lobuled within xvi-xx; duct S-shaped, enlarged basally. Accessory glands sessile massed corresponding to external genital markings.

\section{DNA barcode}

COI barcode data (partial) is for the paratypes uploaded to GenBank under the accession numbers MW076201, MW076202 and MW076203. The new species shares the identity of $85.8 \%$ and $86.1 \%$ with Amynthas sp. (KT252973, KT205464).

\section{Habitat}

The species was found in the leaf litter of soil layer at a depth of 0-10 cm, near streams, and scattered on Con Son Island.

\section{Variations}

There are two morphological types found on Con Son Island. The first type was found in natural forests, with the presence of reddish-brown stripes, a bigger size $(1=133-170 \mathrm{~mm}, \mathrm{~d}=5.0-6.5 \mathrm{~mm})$, the first dorsal pore in 13/14 and ventral distance between spermathecal pores ca $0.38-0.4$ body circumference. The second type found in residential gardens and forest edges exhibited no stripes, a smaller size $(1=64$ $122 \mathrm{~mm}, \mathrm{~d}=3.0-3.4 \mathrm{~mm}$ ), the first dorsal pore in $12 / 13$ and ventral distance between spermathecal pores ca $0.43-0.45$ body circumference. The COI genetic distance also showed the variations of $2.2-11.3 \%$.

\section{Remarks}

A few Metaphire species have been described with five pairs of spermathecal pores, including M. megascolidioides and M. fordi Michaelsen, 1934. The new species is very similar to M. megascolidioides with its first dorsal pore in 12/13 and an absence of genital markings in the spermathecal region. However, M. decemtheca sp. nov. is distinguished by having male pores on xviii, a pair of genital markings in xviii, separate intestinal caeca and a small size $(1=64-185 \mathrm{~mm}, \mathrm{~d}=3.0-6.0 \mathrm{~mm})$ whereas $M$. megascolidioides has male pores on xix, three pairs of genital markings in xvii, xviii and xx, manicate intestinal caeca and a larger size $(1=240 \mathrm{~mm}$, $\mathrm{d}=15 \mathrm{~mm})$.

The new species is also distinguished from $M$. fordi by having a larger size $(1=64-185 \mathrm{~mm}, \mathrm{~d}=3.0$ $6.0 \mathrm{~mm}$ vs $1=50-64 \mathrm{~mm}, \mathrm{~d}=1-1.5 \mathrm{~mm}$ ) and the first dorsal pore in 12/13 (vs 11/12). Additionally, $M$. decemtheca sp. nov. has no genital markings in the spermathecal region, but does have one pair of large, round genital markings located next to the openings of copulatory pouches in xviii. By contrast, $M$. fordi has small circular papillae paired in both spermathecal and male regions.

In terms of the morphology of the male region, the new species is very similar to $M$. grandiverticulata Nguyen \& Lam, 2017 by having a pair of large, round genital markings located next to the openings of its copulatory pouches and an absence of genital markings in the spermathecal region. However, M. decemtheca sp. nov. has five pairs of spermathecal pores on 4/5/6/7/8/9, a larger size $(1=64-185 \mathrm{~mm}, \mathrm{~d}=3.0-6.0 \mathrm{~mm})$, connected testis sacs, oval-shaped spermathecal ampulla, stout ducts, strongly and constrainedly waved diverticula and a small oval-shaped seminal chamber. Meanwhile, M. grandiverticulata has four pairs of spermathecal pores on 5/6/7/8/9, a smaller size $(1=69-92 \mathrm{~mm}, \mathrm{~d}=2.3-2.7 \mathrm{~mm})$, separated testis sacs, a small heart-shaped spermathecal ampulla, extremely short muscular ducts, stout and long unwaved diverticula and a bullet-shaped seminal chamber. 
Table 4. The K2P intra- and interspecific genetic distances between Metaphire species using the 609 bp COI fragment. The intraspecific distances are in bold.

\begin{tabular}{|c|c|c|c|c|c|c|c|}
\hline M. bahli & M. peguana & M. iranomala & M. grandiverticulata & M. decemtheca & M. anomala & M. megascolidioides & Po. elongata \\
\hline \multicolumn{8}{|l|}{$0.008 \pm 0.002$} \\
\hline $0.166 \pm 0.017$ & $0.028 \pm 0.005$ & & & & & & \\
\hline $0.183 \pm 0.017$ & $0.185 \pm 0.017$ & $0.062 \pm 0.007$ & & & & & \\
\hline $0.209 \pm 0.019$ & $0.235 \pm 0.022$ & $0.206 \pm 0.019$ & $0.023 \pm 0.005$ & & & & \\
\hline $0.179 \pm 0.017$ & $0.199 \pm 0.018$ & $0.175 \pm 0.016$ & $0.183 \pm 0.017$ & $0.081 \pm 0.011$ & & & \\
\hline $0.177 \pm 0.018$ & $0.194 \pm 0.019$ & $0.130 \pm 0.014$ & $0.202 \pm 0.020$ & $0.178 \pm 0.017$ & $0.003 \pm 0.002$ & & \\
\hline $0.224 \pm 0.021$ & $0.191 \pm 0.018$ & $0.173 \pm 0.017$ & $0.201 \pm 0.020$ & $0.177 \pm 0.018$ & $0.172 \pm 0.018$ & $0.003 \pm 0.002$ & \\
\hline $0.175 \pm 0.018$ & $0.180 \pm 0.018$ & $0.181 \pm 0.017$ & $0.194 \pm 0.020$ & $0.166 \pm 0.016$ & $0.177 \pm 0.018$ & $0.187 \pm 0.018$ & $0.002 \pm 0.002$ \\
\hline
\end{tabular}

\section{Molecular analysis}

\section{Statement of DNA dataset}

The COI dataset comprises a 609 bp fragment from 36 sequences of 8 earthworm species including an outgroup species, Polypheretima elongata (Table 1). The nucleotide frequencies of A, T, G and C were $29.7 \%, 28.7 \%, 18.6 \%$ and $23.0 \%$, respectively. The GC content was $41.6 \%$. The combined dataset contained $210(34.5 \%)$ parsimony informative and $216(35.5 \%)$ variable sites.

\section{Genetic distance}

The average K2P distance is $16.0 \%$ between earthworm morphospecies. The K2P distance between species varies from $13.0 \%$ (Metaphire iranomala sp. nov. and M. anomala) to $23.5 \%$ (M. peguana and $M$. grandiverticulata). The intraspecific distance varies from $0.2 \%$ (Polypheretima elongata, M. megascolidioides) to $8.0 \%$ (M. decemtheca sp. nov.). The new species, $M$. decemtheca sp. nov., has the K2P divergence of $17.7 \%$ with $M$. megascolidioides and of $18.3 \%$ with $M$. grandiverticulata (Table 4).

The species Metaphire iranomala sp. nov. has genetic variations of $0.2 \%$ to $9.4 \%$. The maximum distance between two types is $9.4 \%$, but it is considered to be less than the average distance of $16 \%$. Therefore, it is suggested that two morphological types still reflect one species. Similarly, the species $M$. decemtheca sp. nov. also has genetic divergences of $2.2 \%$ to $11.3 \%$ corresponding to morphological variations.

The K2P species divergences were reported, but were different for earthworm groups, for example, 13-15\% for Allolobophora Eisen, 1874 (King et al. 2008), 13.2\% for Eisenia fetidalandrei complex (Römbke et al. 2016), more than $14 \%$ in Octolasion lacteum Örley, 1885, Lumbricus rubellus Hoffmeister, 1843 (Klarica et al. 2012), more than 18.7\% in pheretimoid species (Chang et al. 2008), $19.8 \%$ in the genus Lumbricus Linnaeus, 1758 (James et al. 2010), 8.9-22.9\% in the genus Pheretima Kinberg, 1867, 14.2-21.9\% in the genus Amynthas Kinberg, 1867, 7.5-18.0\% in the genus Pithemera Sim \& Easton, 1972 and 11.7-21.0\% in the genus Polypheretima Michaelsen, 1934 (Aspe \& James 2018). Recently, Jeratthitikul et al. (2017) also calculated the average species distance of $20 \%$ for Amynthas and Metaphire species in Thailand. Our calculation of $16 \%$ only applies to the Metaphire species.

\section{Phylogenetic relationship}

A phylogenetic tree was reconstructed for a $609 \mathrm{bp}$ dataset using the Likelihood ML and Inference BI analysis(Fig. 4). Two new species are clearly separated from their congeners. Metaphireiranomala sp. nov. 
is a sister clade of M. anomala with strong supports of bootstrap and BI values $(90 \%$ and $1.00 \mathrm{bpp}$, respectively). Two subclades of $M$. iranomala sp. nov. are also well supported with bootstrap and BI values ( $89 \%$ and $0.92 \mathrm{bpp}$, respectively).

Metaphire decemtheca $\mathrm{sp}$. nov. is related to M. grandiverticulata and M. megascolidioides with moderate bootstrap support and strong BI values of $75 \%$ and $0.95 \mathrm{bpp}$. Within the clade of $M$. decemtheca sp. nov., two morphological variations also represent two linages: CTU-EW.183.06 and CTU-EW.183.p02 + CTUEW.183.03. The relationship is well supported with bootstrap of $96 \%$ and BI value of $1.00 \mathrm{bpp}$.

\section{Discussion}

Nguyen et al. (2016) provided the comprehensive checklist of 212 earthworm species in Vietnam. Earthworms have been well surveyed in most areas in Vietnam, but not in highly mountainous or remote areas. For example, earthworms on islands still have been poorly recognised, except some data in Nam Du (Michaelsen 1934), Con Son (Thai et al. 2004), Lai Son, Hon Tre, Nam Du and Phu Quoc (Nguyen et al. 2017a, 2020). Several species were also recently described from Lai Son Island and Phu Quoc Island (Nguyen et al. 2017a, 2020). It is thus suggested that more intensive surveys in islands of Vietnam would bring more new taxa to discovery.

Nguyen et al. (2016) also suggested some species should be revised or rechecked to confirm their taxonomic status because those species, which were recorded in Vietnam, differentiated from original

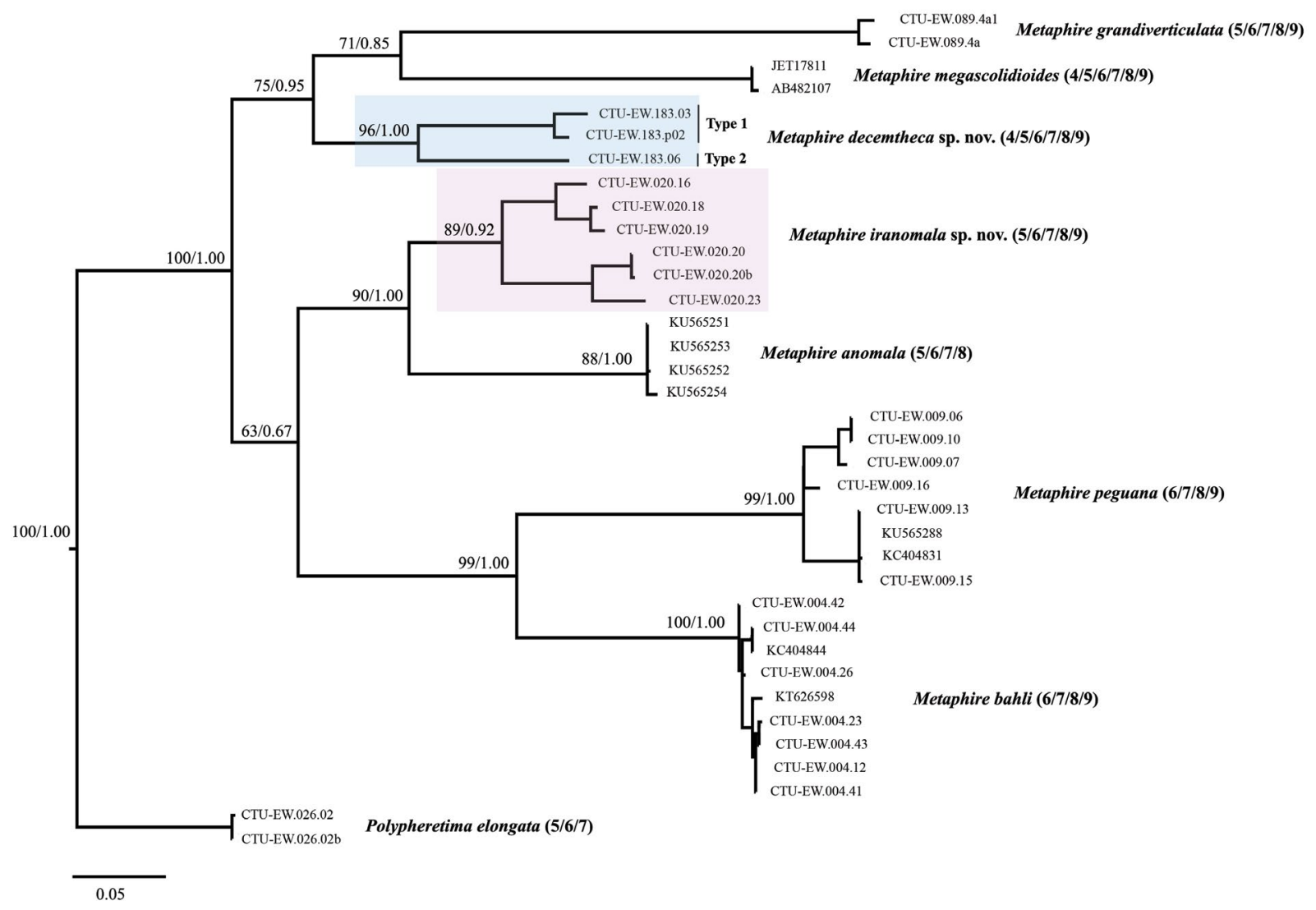

Fig. 4. The phylogenetic diagram inferred from the $594 \mathrm{bp}$ dataset using the Maximum Likelihood (ML) and Bayesian Inference (BI) analysis. The values at node show the bootstrap and BI. The information in parentheses are locations and number of spermathecal pores. 
descriptions, e.g., Metaphire multitheca (Chen, 1938), M. anomala (Michaelsen, 1907). These records of M. multitheca and M. anomala in Vietnam have been corrected and found to be new species, M. erroneous Nguyen \& Nguyen, 2015 and M. iranomala sp. nov.

The high intraspecific divergences in Metaphire iranomala sp. nov. and M. decemtheca sp. nov. may suggest more Vietnamese species containing these cryptic forms, such as M. houlleti (Perrier, 1872) (as discussed in Nguyen et al. 2018). The cryptic speciation events have also been reported in many earthworm species using either mitochondrial data (King et al. 2008; James et al. 2010; Novo et al. 2010) or nuclear data (Rougerie et al. 2009). The COI barcode was also applied to discriminate earthworm species and to suggest cryptic forms (Jeratthitikul et al. 2017).

\section{Acknowledgements}

This research is funded by Vietnam National Foundation for Science and Technology Development (NAFOSTED) under grant number 106.05-2018.04. This study is funded in part by the CTU Improvement Project VN14-P6, supported by a Japanese ODA loan. The English was checked and polished by Ms Kelly Morgan (TRACE Wildlife Forensics Network).

\section{References}

Aspe N.M. \& James S.W. 2018. Molecular phylogeny and biogeographic distribution of pheretimoid earthworms (Clitellata: Megascolecidae) of the Philippine archipelago. European Journal of Soil Biology 85: 89-97. https://doi.org/10.1016/j.ejsobi.2018.02.001

Bantaowong U., Chanabun R., Tongkerd P., Sutcharit C., James S.W. \& Panha S. 2011. A new species of the terrestrial earthworm of the genus Metaphire Sims and Easton, 1972 from Thailand with redescription of some species. Tropical Natural History 11 (1): 55-69.

Blakemore R.J. 2016a. Darwin's earthworms (Annelida, Oligochaeta, Megadrilacea) with review of cosmopolitan Metaphire peguana-species gr oup from Philippines. Opuscula Zoologica 47 (1): 9-30. https://doi.org/10.18348/opzool.2016.1.9

Blakemore R.J.2016b.Eco-taxonomic profileand mtDNAbarcode of Metaphiremegascolidioides (Goto \& Hatai, 1899) - a megadrile earthworm from Japan, plus miscellaneous taxonomic mending. VermEcology Occasional Papers 1: 1-16.

Chang C.-H., Lin S.-M. \& Chen J.-H. 2008. Molecular systematics and phylogeography of the gigantic earthworms of the Metaphire formosae species group (Clitellata, Megascolecidae). Molecular Phylogenetics and Evolution 49: 958-968. https://doi.org/10.1016/j.ympev.2008.08.025

Chen Y. 1938. Oligochaeta from Hainan, Kwangtung. Contributions from the Biological Laboratory of the Science Society of China. Zoological Series 12 (10): 375-427.

Cognetti M.L. 1908. Contributo alla conscenza della drilofauna papuasica. Bollettino dei musei di zoologia ed anatomia comparata della $R$. Università di Torino 23 (584): 1-4.

Edgar R.C. 2004. MUSCLE: a multiple sequence alignment method with reduced time and space complexity. BMC Bioinformatics 5: 113. https://doi.org/10.1186/1471-2105-5-113

Feldman A.T. \& Wolfe D. 2014. Tissue processing and hematoxylin and eosin staining. In: Day C. (ed.) Histopathology. Methods in Molecular Biology (Methods and Protocols) 1180: 31-43. Humana Press, New York.

Folmer O., Black M., Hoeh W., Lutz R. \& Vrijenhoek R. 1994. DNA primers for amplification of mitochondrial cytochrome c oxidase subunit I from diverse metazoan invertebrates. Molecular Marine Biology and Biotechnology 3: 294-299. 
NGUYEN T.T. et al., Two new Metaphire species from Southern Vietnam

Gates G.E. 1925. Some notes on Pheretima anomola, Mich. and a related species new to India and Burma. Annals and Magazine of Natural History 15 (9): 538-550. https://doi.org/10.1080/00222932508633244

Gates G.E. 1972. Burmese earthworms: an introduction to the systematics and biology of Megadrile oligochaetes with special reference to Southeast Asia. Transactions of the American Philosophical Society 62: 1-326. https://doi.org/10.2307/1006214

Goto S. \& Hatai S. 1899. New or imperfectly known species of earthworm. Annotationes Zoologicae Japonenses 3 (2): 13-24.

Hall T.A. 1999. BioEdit: a user-friendly biological sequence alignment editor and analysis program for windows 95/98/NT. Nucleic Acids Symposium Series 41: 95-98.

James S.W., Porco D., Decaens T., Richard B., Rougerie R. \& Ersaeus C. 2010. DNA barcoding reveals cryptic diversity in Lumbricus terrestris L., 1758 (Clitellata): resurrection of L. herculeus (Savigny, 1826). PLoS One 5: e15629. https://doi.org/10.1371/journal.pone.0015629

Jeratthitikul E., Bantaowong U. \& Panha S. 2017. DNA barcoding of the Thai species of terrestrial earthworms in the genera Amynthas and Metaphire (Haplotaxida: Megascolecidae). European Journal of Soil Biology 81: 39-47. https://doi.org/10.1016/j.ejsobi.2017.06.004

Kalyaanamoorthy S., Minh B.Q., Wong T.K.F., von Haeseler A. \& Jermiin L.S. 2017. ModelFinder: fast model selection for accurate phylogenetic estimates. Nature Methods 14: 587-589.

https://doi.org/10.1038/nmeth.4285

King R.A., Tibble A.L. \& Symondson W.O.C. 2008. Opening a can of worms: unprecedented sympatric cryptic diversity within British lumbricid earthworms. Molecular Ecology 17: 4684-4698.

https://doi.org/10.1111/j.1365-294X.2008.03931.x

Klarica J., Kloss-Brandsttätter A., Traugott M. \& Juen A. 2012. Comparing four mitochondrial genes in earthworms - implications for identification, phylogenetics, and discovery of cryptic species. Soil Biology and Biochemistry 45: 23-30. https://doi.org/10.1016/j.soilbio.2011.09.018

Kumar S., Stecher G. \& Tamura K. 2016. MEGA 7: Molecular Evolution Genetics Analysis version 7.0 for bigger datasets. Molecular Biology and Evolution 33: 1870-1874.

https://doi.org/10.1093/molbev/msw054

Michaelsen W. 1907. Neue Oligochäten von Vorder-Indien, Ceylon, Burma und den Andaman-Inseln. Mitteilungen aus dem naturhistorischen Museum in Hamburg 24: 143-193.

Minamiya Y., Yokoyama J. \& Fukuda T. 2009. A phylogeographic study of the Japanese earthworm, Metaphire sieboldi (Horst, 1883) (Oligochaeta: Megascolecidae): inferences from mitochondrial DNA sequences. European Journal of Soil Biology 45 (5/6): 423-430.

https://doi.org/10.1016/j.ejsobi.2009.06.004

Minh B.Q., Schmidt H.A., Chernomor O., Schrempf D., Woodhams M.D., von Haeseler A. \& Lanfear R. 2020. IQ-TREE 2: new models and efficient methods for phylogenetic inference in the genomic era. Molecular and Biological Evolution 37: 1530-1534. https://doi.org/10.1093/molbev/msaa015

Nguyen A.D. \& Nguyen T.T. 2015. Notes on Metaphire multitheca (Chen, 1938) (Oligochaeta, Megascolecidae) recorded from Vietnam, with descriptions of two new species. ZooKeys 506: 127136. https://doi.org/10.3897/zookeys.506.9550

Nguyen Q.N., Nguyen V.T., Duong C.T., Le V.N. \& Nguyen T.T. 2019. Species diversity of earthworms in Dong Nai Province, Vietnam. Tap Chi Sinh Hoc 41 (2): 117-129. 
Nguyen T.T. 2014. Checklist and some remarks on faunistic characteristics of earthworms in the Mekong Delta, Vietnam. Journal of Science, Cantho University, Section A: Science, Technology and Environment 32: 106-119.

Nguyen T.T \& Lam H.D. 2017. Three new earthworm species of the genus Metaphire Sims \& Easton, 1972 (Oligochaeta, Megascolecidae) from Dong Nai Province, Vietnam. Tap Chi Sinh Hoc 39 (4): 406415.

Nguyen T.T., Nguyen A.D., Tran T.T.B. \& Blakemore R.J. 2016. A comprehensive checklist of earthworm species and subspecies from Vietnam (Annelida: Clitellata: Oligochaeta: Almidae, Eudrilidae, Glossoscolecidae, Lumbricidae, Megascolecidae, Moniligastridae, Ocnerodrilidae, Octochaetidae). Zootaxa 4140: 1-92. https://doi.org/10.11646/zootaxa.4140.1.1

Nguyen T.T., Trinh K.B.T., Nguyen H.L.T. \& Nguyen A.D. 2017a. Earthworms (Annelida: Oligochaeta) from islands of Kien Hai District, Kien Giang Province, Vietnam, with descriptions of two new species and one subspecies. Journal of Natural History 51 (15-16): 883-915.

https://doi.org/10.1080/00222933.2017.1294213

Nguyen T.T., Nguyen P.H., Truong T.A. \& Nguyen Q.N. 2017b. Diversity and distribution of earthworms in Ba Ria, Vung Tau Province. Journal of Science, Can Tho University 53 (A): 96-107.

Nguyen T.T., Nguyen Q.N \& Nguyen A.D. 2018. First record of the earthworm genus Pheretima Kinberg, 1867 sensu stricto in Vietnam, with description of a new species (Annelida: Clitellata: Megascolecidae). Zootaxa 4496 (1): 251-258. https://doi.org/10.11646/zootaxa.4496.1.20

Nguyen T.T., Lam D.H., Trinh B.T.K. \& Nguyen A.D. 2020. The megascolecid earthworms (Annelida, Oligochaeta, Megascolecidae) in the Phu Quoc island, Vietnam, with descriptions of three new species. ZooKeys 932: 1-25. https://doi.org/10.3897/zookeys.932.50314

Novo M., Almodovar A., Fernandez R., Trigo D. \& Díaz-Cosín D.J. 2010. Cryptic speciation of hormogastrid earthworms revealed by mitochondrial and nuclear data. Molecular Phylogenetics and Evolution 56: 507-512. https://doi.org/10.1016/j.ympev.2010.04.010

Prasankok P., Bantaowong U., James S.W. \& Panha S. 2013. Low heterogeneity in populations of the terrestrial earthworm, Metaphire peguana (Rosa, 1890), in Thailand, as revealed by analysis of mitochondrial DNA CO1 sequences and nuclear allozymes. Biochemical Systematics and Ecology 51: 8-15. https://doi.org/10.1016/j.bse.2013.07.001

Römbke J., Aira M., Backeljau T., Breugelmans K., Domínguez J., Funke E., Graf N., Hajibabaei M., Perez-Losada M., Porto P.G., Schmelz R.M., Vierna J., Vizcaíno A. \& Pfenninger M. 2016. DNA barcoding of earthworms (Eisenia fetidalandrei complex) from 28 ecotoxicological test laboratories. Applied Soil Ecology 104: 3-11. https://doi.org/10.1016/j.apsoil.2015.02.010

Ronquist F., Teslenko M., van der Mark P., Ayres D.L., Darling A., Höhna S., Larget B., Liu L., Suchard M.A. \& Huelsenbeck J.P. 2012. MrBayes 3.2: Efficient Bayesian phylogenetic inference and model selection across a large model space. Systematic Biology 61: 539-542.

https://doi.org/10.1093/sysbio/sys029

Rougerie R., Decaens T., Deharveng L., Porcol D., James S.W., Chang C.-H., Richard B., Potapov M., Suhardjono Y. \& Hebert P.D.N. 2009. DNA barcodes for soil animal taxonomy. Pesquisa Agropecuária Brasileira 44: 789-801. https://doi.org/10.1590/S0100-204X2009000800002

Sims R.W. \& Easton E.G. 1972. A numerical revision of the earthworm genus Pheretima auct. (Megascolecidae: Oligochaeta) with the recognition of new genera and an appendix on the earthworms collected by the Royal Society North Borneo Expedition. Biological Journal of the Linnean Society 4: 169-268. https://doi.org/10.1111/j.1095-8312.1972.tb00694.x 
Stephenson J. 1929. The Oligochaeta of the lndawgyi lake (upper Burma). Records of the Indian Museum 31: 225-239.

Thai T.B., Huynh T.K.H. \& Nguyen D.A. 2004. Remarks of earthworms on the islands in southern of Vietnam. Proceedings of the national Workshop on the basic Issues in Life Science. Hanoi Science and Technics Publishing House: 757-760.

Yuan Z., Dong Y., Jiang J., Jiang J., Zhao Q. \& Qiu J. 2019. Three new species of earthworms (Oligochaeta: Megascolecidae) from Yunnan Province, China. Zootaxa 4664 (3): 390-400. https://doi.org/10.11646/zootaxa.4664.3.6

Zhang Z., Schwartz S., Wagner L. \& Miller W. 2000. A greedy algorithm for aligning DNA sequences. Journal of Computational Biology 7 (1-2): 203-214. https://doi.org/10.1089/10665270050081478

Manuscript received: 6 October 2020

Manuscript accepted: 22 December 2020

Published on: 21 April 2021

Topic editor: Rudy C.A.M. Jocqué

Desk editor: Charlotte Gérard

Printed versions of all papers are also deposited in the libraries of the institutes that are members of the EJT consortium: Muséum national d'Histoire naturelle, Paris, France; Meise Botanic Garden, Belgium; Royal Museum for Central Africa, Tervuren, Belgium; Royal Belgian Institute of Natural Sciences, Brussels, Belgium; Natural History Museum of Denmark, Copenhagen, Denmark; Naturalis Biodiversity Center, Leiden, the Netherlands; Museo Nacional de Ciencias Naturales-CSIC, Madrid, Spain; Real Jardín Botánico de Madrid CSIC, Spain; Zoological Research Museum Alexander Koenig, Bonn, Germany; National Museum, Prague, Czech Republic. 